この 8 月 (77年) の 1 カ月を南アフリカ共和国で暮し た。ナタール州のダーバン市から北上してトランスバー ル州に入り，ヨハネスブルグ市の郊外功東向してモザ ンピークとの国境に通ずるハイウエイの大半は, 大炭田 に沿っているので, 各地で採・選炭プラントが望見でき る。ちなみに, ナタール州のリチャードベイの積込み施 設をへて多量の石炭が日本に輸出されている。またヨ八 ネスブルグ市に入れば，周知のウィットウォーターズラ ンド金鉱床があり，現在なお残存鉱脈が稼行され，選鉱 プラントが操業されている。もちろん規模は小さい。

とのような刺激に誘発され, 下調べあなしで, ウィ ットウォーターズランド大学 ( 7 学部) の工学部採鉱学 科の岩石力学教室を訪問, すでに進行中の大規模金鉱床 の開発・稼行に関係する S. Budavari 教授の坑道・坑井 の変形值の予測についての説明をうけたあと, 郊外のラ ンドベルク市にある国立冶金研究所（研究の主部門一理 学系 3 , 工学系 4。職員 646。66年 設立) の選鉱部門 (部員46, うち学卒以上16) のパイロットプラントを L. Levin 部長の案内で見学し，との過程で写真 1 に示すよ うなドライフローセパレータのモデル 30 （デッキ面積 $\left.930 \mathrm{~cm}^{2}\right)$ に触れるととができた。蛇足を加えれば， 1 は台形の振動デッキで多孔質の金属板からなり，2 はエ ヤーボックス（空気压は水銀柱16时以下）である。

南アフリカでは選鉱用水に乏しい地域が多いので, 乾 式セパレータで低品位鉱に予選し，ついで用水に恵れた

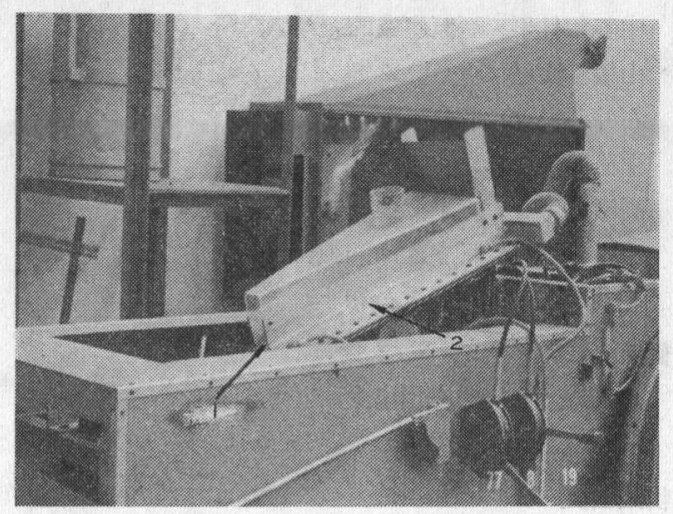

写真 1

* 本会会員 相模原市相武台団地1510-46 昭和52年 9 月 21 日受理
林 大 輔*
地点に運び，本選鉱にかける例が多いというととであっ た。

振動デッキから空気を吹出すととによって粒体群の流 動性を高め, 比重差による成層を実現していると考えら れるこのようなセパレータは, 振動輸送の過程に付帯す る現象を利用しているという点からすれば，振動輸送機 に分類してあ差支えないであろう。ふつう，粒径差によ る成層の度合いも効率に関係するとされている振動スク リーンあ, この分類に属している。

一般に振動輸送機におりる振動面上の被輸送原料の運 動機構にたいする解析は単一粒体による報告が多く, 粓 体群に単純拡張のできないばあいが多い。群粒体として の考察にもとづく研究もあるが, 振動強度が小さく滑り 運動や粒子のとび上がりの小さいばあいにその適用が限 られている1。振動スクリーンのように振動強度が大き く，とび上がりが大きい機械では，粒子間の相互作用や 堆積時におりる粒子の位置のとび上がりの位相角にたい する相違は考慮されていても, 粒径差は無視されてい る2。結局粒体群の挙動にたいする実験的研究が不足し ているととによる。

とのような事情からすれば, 適正な吹出し空気量と整 粒度そのほかの条件のあとで，はじめて比重にしたがっ た成層が実現できるとするドライフローセパレータの性 能は，ほかの振動輸送機のデッキ上の粒体群の混合・成 層・偏析現象を考察するばあいの参考資料の一つとなる といえよう。

このような見地から J. Levin 部長に教示をあおいだ ところ, 効率の良い比重選鉱の条件を求めるための研究 を目的としてきたので，極端条件でのデータは記録して いないが, 空気量一つだけであ，その多少により乱雑な 混合現象が示されたり，粒径に偏よった成層が現われた りしたということであり,とりあえずといって部員 P.W. Overbeek 氏の報告3)を与えられた。

この報告をお読みになった方々は多いと考えられるが， 抄訳の意味で紹介するとつぎのようである。

実験用の機械は写真で示したモデル30。供試した原料 は表 1 に示すような比率で石英粉に比重と化学成の違っ た鉱石粉をマーカーとして配合したもの。石英と各鉱石 それぞれの粉末は，いずれす表 2 に示す粒度分布をすつ ように調整され，乾燥・秤量・混合して供試料とされる。 
表 1

\begin{tabular}{|c|c|c|c|}
\hline 鉱 & \begin{tabular}{r|} 
配合比率 \\
$\%$
\end{tabular} & 比 重 & $\begin{array}{l}\text { 分析の対象 } \\
\text { 亡した成分 }\end{array}$ \\
\hline 石 & 85.0 & 2.65 & 一 \\
\hline 燐 灰 石 & 5.0 & 3.19 & $\mathrm{P}_{2} \mathrm{O}_{5}$ \\
\hline 仮焼菱苦上鉱 & 4.0 & 3.42 & $\mathrm{MgO}$ \\
\hline クローム鉄鉱 & 3.0 & 4.47 & $\mathrm{Cr}_{2} \mathrm{O}_{3}$ \\
\hline 鉛 硝 & 2.0 & 5.43 & $\mathrm{~Pb}$ \\
\hline 錫 & 1.0 & 6.79 & $\mathrm{Sn}$ \\
\hline
\end{tabular}

表 2

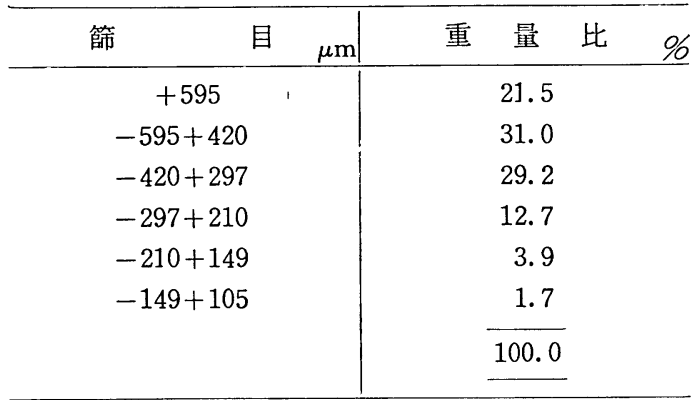

表 3

A. 試験結果の例

\begin{tabular}{rr|r|r|r|r|r|r}
\hline & \multirow{2}{*}{ 産 } & 物 & 重量比 & \multicolumn{3}{|c|}{ 分 } & \multicolumn{2}{|c|}{ 析 } & 值 \% \\
\cline { 3 - 8 } & & $\%$ & $\mathrm{P}_{2} \mathrm{O}_{5}$ & $\mathrm{MgO}$ & $\mathrm{Cr}_{2} \mathrm{O}_{3}$ & $\mathrm{~Pb}$ & $\mathrm{Sn}$ \\
\hline 精 & 鉱 & 29.3 & 2.03 & 8.87 & 5.41 & 5.30 & 4.93 \\
尾 & 鉱 & 70.7 & 1.10 & 2.11 & 0.32 & 0.04 & 0.02 \\
給 & 鉱 & 100.0 & 1.37 & 4.11 & 1.82 & 1.57 & 1.47 \\
\hline
\end{tabular}

\begin{tabular}{|c|c|c|c|}
\hline \multicolumn{2}{|c|}{ B. 分布指数の計算值 } & \multirow{8}{*}{$\begin{array}{l}\text { 分離比重 } \\
\text { 確率悞差 }\end{array}$} & \multirow{3}{*}{$\begin{aligned}\left(\mathrm{d}_{50}\right) & =3.35 \\
\mathrm{Ep} & =0.50\end{aligned}$} \\
\hline 比重 & $\begin{array}{l}\text { 精鉱中の収率 } \\
\text { または } \\
\text { 分布 指 数 }\end{array}$ & & \\
\hline 6.79 & 99.3 & & \\
\hline 5.43 & 98.2 & & \\
\hline 4.47 & 87.5 & & \\
\hline 3.43 & 63.5 & & \\
\hline 3.19 & 43.4 & & \\
\hline 2.65 & 20.3 & & \\
\hline
\end{tabular}

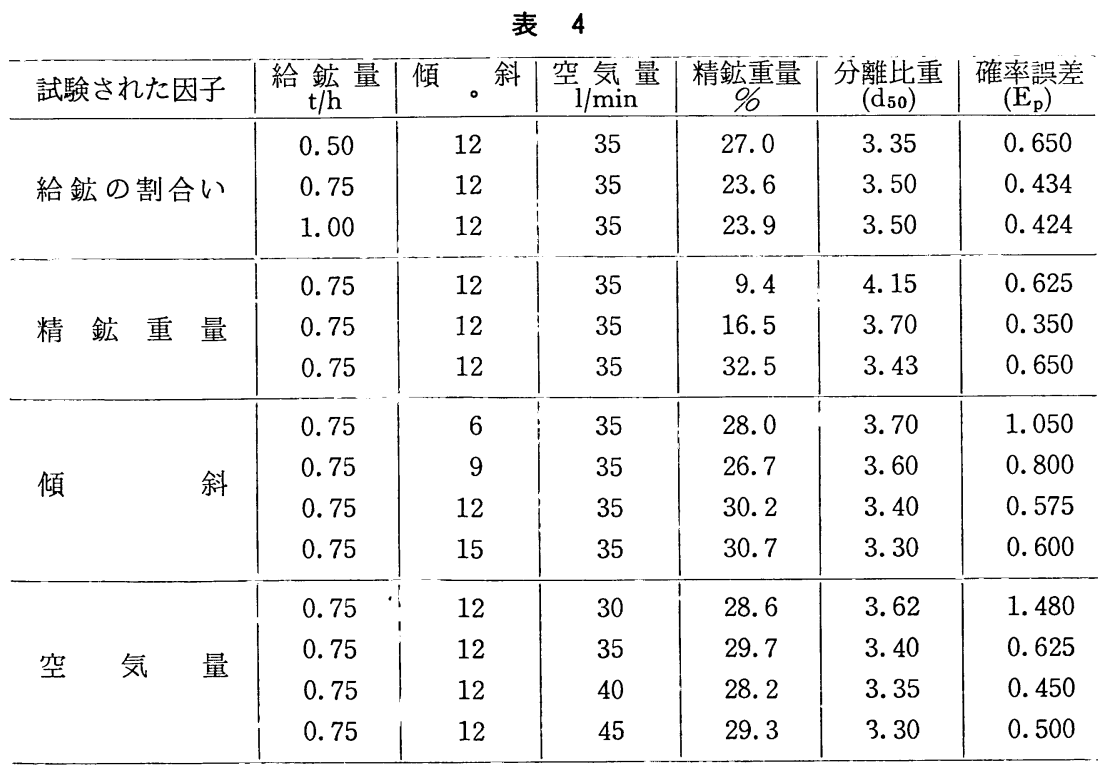


表 5

\begin{tabular}{c|c|c|c} 
粒 & $\begin{array}{c}\text { 精鉱中の } \\
\text { 分布比率 }\end{array}$ & $\begin{array}{c}\text { 分離比重 } \\
\left(\mathrm{d}_{50}\right)\end{array}$ & $\begin{array}{c}\text { 確率俁差 } \\
\left(\mathrm{E}_{\mathrm{p}}\right)\end{array}$ \\
\hline+595 & 44.0 & 2.80 & 0.37 \\
$-595+420$ & 34.0 & 3.00 & 0.46 \\
$-420+297$ & 23.7 & 3.40 & 0.60 \\
$-297+210$ & 17.1 & 3.90 & 0.78 \\
-210 & 0 & 0 & 0 \\
全 精 鉱 & 30.2 & 3.40 & 0.575 \\
\hline
\end{tabular}

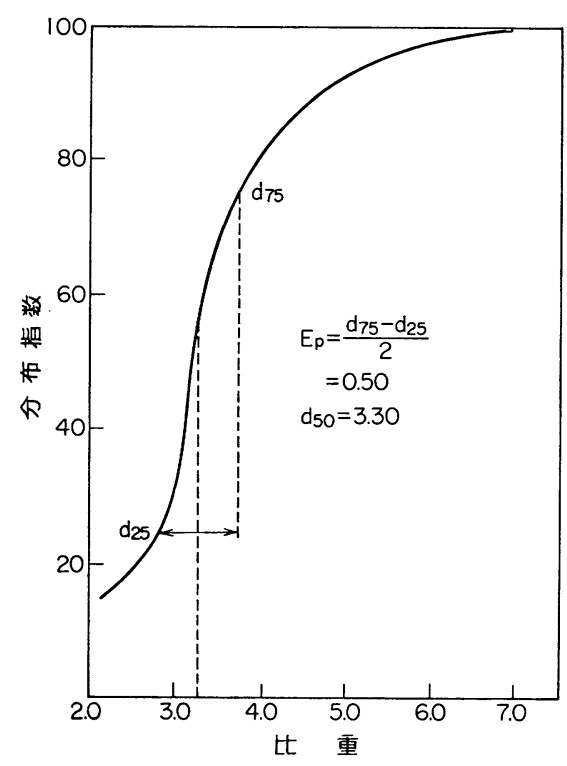

図1トロンプ曲線

セパレータからの排出原料の分割はスキンマーによる。

実験結果の 1 例を示すと表 3 の A B Bようになり, トロンプ曲線を描くと第 1 図のようになって分離比重 $\left(\mathrm{d}_{50}\right)=3.35$, 確率誤差 $\mathrm{E}_{\mathrm{p}}=0.50$ となる。実験条件をかえ， このような例にならって結果をまとめると表 4 亿示すよ うになる。また粒径差による分級作用の証しを示すと表 5 の例のようになる。

以上の報告には, 振動デッキの振動数・振幅の記載や 粒体群の挙動にたいする観察に欠けているので, 一般の 振動輸送機における粒体群の運動と比較しての力学的な

\section{大 輔}

考察は到底できないが，とああれ，適正な空気量をデッ キ面から吹出すことによって比重差による粒体の運動の 相違を極力生加すうに計っても，な扐かつ，比重差に 相当する整粒を考慮しない限り，粒径による分級作用が 残存するてとを証明しているといえよう。とすれば，た んに鉱石のセパレータについてばかりでなく，一般の振 動輸送機にとっても参考となる資料を報告はふくんでい る。

この国立冶金研究所の建物は，中高層ビル 2 棟をふく めて最近 5 年間に増設された部分が多く, 清楚な佇いで あり, 中庭の広い花壇が赤・黄とあざやかで美しかった が，業務はきわめて繁忙らしく，選鉱のパイロットプラ ントあ機械の組替えが絶えず行われているようであった。 国営企業の増大ばかりでなく，民族資本による鉱山会社 への助成・指導が強化されているととを考えれば当然の ことであろう。一般の選鉱事情についてあ拝聞したが, そのような事情の紹介は著者の任でないので全て省略し， このところ多読している振動運搬機にたいする研究報告 に関連したドライフローセパレータだけに記述を限った わけである。なお，このプラントでは格別の考案を加え たと推察される磁選機あ見受けられた。ドライフローセ パレータと同様に乾燥地域における予選鉱に使用するた め研究とのととであった。

\section{引用 文 献}

1）坂口克己・谷口 修: 粉粒体の振動輸送。日本機械 学会論文集, 38巻305号, 頁103-115, 昭47-1。

坂口克己：粉粒体の振動輸送。日本機械学会論文集, 42巻361号, 頁2734-2743, 昭51-9。

2) Б. И. КРЮКОВ Ж.Д. МАЗЯР: МЕХАНИКА ДВИЖЕНИЯ НАСЫПНОГО МАТЕРИАЛА ПО РАБОЧЕМУ ОРГАНУ ВИБРАЦИОННЫХ МАШИН. "ПРОБЛЕМЫ ВИБРАЦИОННОЙ ТЕХНИКИ, 《НАУКОВА ДУМКА》 АТР. 149164, 1968.

3) P. W. Overbeek: An assessment of the efficiency of the dryflo concentrator by the use of specificgravity markers. Journal of south african inst. of mining \& metallurgy, p. 120-122, Oct. 1975. 